\title{
Performance and the politics of distance: Exploring the psychology of identity and culture in politicized Australian performance landscapes
}

\section{ABSTRACT}

The politics of distance in Australia has shaped our history and informed the psychological landscape of Australian cultural identity since settlement and colonization. Distance is a subjective space for Australians, and as a result the national subjectivity can cause significant problems for immigrants, asylum seekers, refugees and exiles from 'other' homelands who experience a disjunction of place and culture, and seek sanctuary. Drawing on current post-colonial Australian anxieties, this research investigates Australian concepts of distance alongside what has become a politically contested Australian racial and cultural agenda. Analysing these issues through the lens of Australian Gothic drama, the article also integrates examples from Hassall's performance research, Salvation (2013), to support the discussion.

\section{KEYWORDS}

Australian Gothic cultural agenda drama research the 'other' politics of distance psychology of identity racial agenda 


\section{INTRODUCTION}

Conflicting notions of distance and the corresponding psychological implications associated with spatial measures in Australia have become so prevalent in the national cultural psyche that they have inspired numerous fragmentary and evocative images, themes and forms for dramatic stimulus and research. Distance and its associated spatial imagining can be acknowledged as a psychological map on which historical memory, cultural difference and social unification are inscribed. In Australia, the inscribed experiences are often interpreted through the 'white' Australian lens. Since transportation and colonization, such conflicting spatial imaginings have been signifying factors in the national consciousness. From the time that Captain James Cook sailed into the harbour of what became known as Botany Bay, the politics, the perception, the collective reverence and indeed the fear of Australia's isolating geographies and menacing distances have informed continuing efforts to find a definitive chronicle of identity, place, peoples and experiences.

In this article, I invite the reader into a thematic exploration of distance through my scholarship as a playwright and creative researcher. It draws on excerpts from the play Salvation and the genre of Australian Gothic drama to provoke discussion on contemporary political tensions associated with race and religion in Australia. Originally forming part of my 2012 Ph.D research, then produced at the Brisbane Powerhouse and published in 2013, Salvation analyses though a theatrical lens social justice issues pertaining to the land, the culture, the environment and the human inhabitants of Australia. The play - and indeed elements of the Australian Gothic genre - pose the idea that the country's geographic isolation from the larger world, coupled with the vast distances within the landscape of the country itself, have informed a nervous duality that politicizes the present through past colonial experiences. In turn, the duality informs the future of a nation that embraces the familiar and excludes the 'other'. In this way, aligned with principles of theatre for social change, Salvation provokes an audience to consider social and national issues from historical and immediate perspectives, through its thematic investigations of colonization, land rights, religious intolerance and white Australian conservatism. Salvation also contributes to the modern Australian Gothic dramatic canon by analysing perceptions of continuing 'white' Australian authority in the current multi-racial politicized landscape.

Salvation provides an example of how contemporary Gothic elements are infused into the drama and investigates what Paul Carter (2010: 349) describes as 'not the physical country but the enactment of a historical space'. In The Road to Botany Bay, he provides a very evocative account of colonizing the landscape. Inspired by his scholarship and his discussion of colonial settlement in Australia, I weave colonial experiences into Salvation's dramatic imaginings of the present and future. Salvation aims to investigate colonizing behaviours, including the overwhelming desire to tame the distance ... to own the land ... to take the country. This is explored in the characters' attempts to claim a place to call home:

Past: Salvation was thought to be found in the great distance. In our yearning to reach into the emptiness of that vast desert space ... to spread ourselves, however thinly across - into - through the horizon. We left white boot-heeled footprints in the dirt. We trod carelessly across the darker bare-footed imprints of those of ancient lines and eternal time. We didn't care. We were seeking Salvation. We took 
little with us into the distance. Nothing of import really ... except God and Justice and Good Intentions. We carried these with us on the backs of dreams of land. Dreams carried in cardboard suitcases and boxes and buckets. Vessels filled with goods and greed and great white hopes. You see, Salvation was ours sayeth the Lord. In Salvation there was promise. The promise-land.

Future: Never mind the genocide. Never mind that. That's a position of perspective. History. We were just moving into the distance eager to meet the promise. The promise of Salvation from the past. The promise of Salvation from poverty and the pain of separation.

Past: We looked into the distance and imagined beyond into the brightest of bright futures.

Future: We could not conceive of what we did ... what we caused ... what we ignored ... what we ... what we ... what we see now from far into the future we couldn't possibly have imagined. We were like children. Like children we understood far too late that promises are empty, miserable things ... like buckets that have no bottoms.

(Hassall 2013: 6)

The above excerpt bears witness to contemporary Australian culture's attempt to come to terms with past settler circumstances. Structurally layering the experiences of the white colonizer through present and future circumstances, Salvation provides an example of how Gothic themes are embedded in places and spaces that promise much and deliver little. Within Salvation, the depiction of Australia is a vast, empty, threatening space, a psychologically incarcerating landscape. It is a place where white Australians encounter intimidating distances and exist in an apocalyptic, existential environment. They pay tribute to the heat, the isolation, the space and the threatening landscape, yet they hope it is a place where they will find comfort, and a land for which they will fight. True to the nature of Gothic literature, there is little hope found in the environment in which the characters find themselves and which they claim. Salvation is an example of how the Gothic genre enables us to explore contemporary social justice issues such as land rights through the lens of Australian drama and performance.

In Australian contemporary performance, the genre can be defined as one that contains a dual purpose: that of uncovering and dissecting historical ties to 'white' mother England while simultaneously exposing our present dis-ease with our colonizing behaviours and our treatment of First Nations peoples of the land. Gothic sensibilities may therefore be acknowledged as a psychological state of mind - an expression of conflicting cultural and environmental contexts in the landscape discourse of the country. Gothic playwrights and scholars are examining conflicting white Australian responses to immigration, refugee settlement and religious intolerance, thereby contributing to current postcolonial debates about race, class, religion and place. The popularity of the Gothic form can therefore be attributed to its undeniable immediacy, linking the dark aesthetic of the Gothic with how Australians past and present apprehend the cultural, racial and land ownership legacies. As such, the national mindset associated with such dramatic explorations is often premised on an embedded white guilt - an historical concern that recognizes historical injustices that are distressing and uncomfortable, and that are being repeated from new perspectives, and to which Reynolds (1999: 258) refers 'as the incubus which burdens us all'. 
Essentially, the Gothic is a popular dramatic form in Australian drama studies, providing a blueprint for examining the contemporary Australian experience through recognisable social, cultural and political landscapes. Australian Gothic has established itself as a distinct field of academic research, in drama education and in contemporary performance analysis as well as in literary and creative writing studies. Its popular emergence as a genre in drama and theatre studies has been accompanied by its addition to some secondary drama syllabus documents, including the Queensland Senior Syllabus. In addition, within university drama programs and other contemporary performance contexts, the identification and examination of Australia as a Gothic space is gaining momentum, especially in devised work that explores the nation's fluctuating political leadership and associated contested experiences of asylum seekers, immigration, stolen generations and First Nation peoples' displacement from the landscape, and religious persecution.

\section{AUSTRALIA AS GOTHIC SPACE}

Australian artistic renderings of life in the colony have reflected the Gothic aesthetic since transportation. As a historically perceived Gothic space in itself, Australia is examined through theatrical elements that convey pervading atmosphere, terrifying distances and unforgiving landscapes - and thematic elements that present the nation's brutal history buried deep within its psychological landscape. By the eighteenth century, and prior to transportation and colonization, Australia existed in the European imagination as a fragmentary terrifying landscape inhabited by monsters and murdering savages, birds that screamed, an unnatural order of seasons, isolating landscapes, terrifying empty expanses and - via the colony's start as a destination of convict transportation - as the dungeon of the world (Turcotte 1998). Australia's establishment as a penal colony took hold in this perceived landscape. With Gothic edifices such as Port Arthur prison settlement, Australia's brutal penal culture coincided with the rise of the Gothic literary genre (Carleton 2012; Gelder and Weaver 2007; Turcotte 1998). Constructed in the eighteenth century and noted as one of the cruellest and most merciless convict goals in recorded history, the Port Arthur penitentiary on the Tasman Peninsula in Tasmania became the site of one of the world's most brutal contemporary massacres in 1996 - an act that, from a Gothic spatial perspective, layered the massacre site into the punishing convict landscape. As settlers and free white Australians claimed ownership of the landscape, Australia became a conflicted nation, caught between settler desires to kill off the entire Aboriginal population and the pastoral requirements to use Aboriginal people as an essential'slave' labour force after claiming their land as the settlers' own (Biskup 1973; McQueen 2004).

From a theatrical perspective, Salvation evokes the tyranny of the perception of the distance as out there - that illusory outback desert landscape that impossible to measure. It is a space that is all distance, where perspective is difficult to pin down and there seems to be a sense of all human perceptions of time being lost. The distance suggests that the country may simultaneously be in advance of time and within it. In Salvation, and indeed in other examples of the genre (Ash et al., 2004; Betzien, 2005, 2007, 2009; Carleton, 2006; Hassall, 2008, 2011, 2015; McGahan and Charles, 2009; Mellor, 2008; Watts, 2007), the landscape's distances - the actual and cultural geography - activate the psychological terrain that motivates behaviours; it is therefore the characters' interactions and behaviour in the landscape that define their identity. The 
prevalent and recognised images of a national identity may seem to be the normal or inexorable product of the collective Australian experience, including images that identify the Australian 'national character' with mateship, the land, the outback and the beach. However, as Whitlock and Carter (2001) suggest, national identity becomes more complex when we begin to reflect on questions about whose experiences of the nation we are discussing. In the following excerpt from Salvation, I explore some heated responses to subjective questions about themes associated with land rights and refugee experiences:

Future: This is their fucking country and it's more than fucking obvious it is not a place for pale skinned society descended from the fucking English criminal class.

Future: Don't you go tellin' me this country isn't mine ... we, they, them, those before us took this country. Bastards took it. I know that. But I had nothin' to do with that ... weren't me. It weren't theirs, but they took it. What the fuck can ya expect ... Murderers, rapists, prostitutes, thieves, preachers ...

Future: $\quad$... original fuckin' boat people.

(Hassall 2013: 8)

An analysis of Gothic spatial sensibilities as represented in this excerpt openly privileges themes of terra nullius, a Latin term meaning 'the land belonging to no one'. The term terra nullius became established in Australia with colonization. It is privileged at the forefront of the drama in order to stimulate discussion about citizenship and dreams of land while dissecting notions of belonging in the contemporary consciousness. Historically, the Aboriginal and Torres Strait Islander population of Australia represented a serious challenge to the moral legitimacy of colonization. As Van Toorn (1992) points out, white transplantation into the black country contradicted the British fiction that Australia, through its legal status as terra nullius, was uninhabited. As Turcotte (1998) and Carleton (2015) demonstrate, the often violent and debauched lives of convicts and early settlers, along with the subsequent and continued 'ghosting' of Aboriginal peoples and their cultures and languages, are still present within the cultural consciousness. They significantly stimulate debate within Australian socio-political discourses that are embedded in historical experiences of terra nullius.

In an analytical exploration of Australia as a Gothic space, scholars, practitioners and students contextualize history and tradition through contemporary lenses as the texts 'speak' across various historical and immediate time periods. As intimated above, the past and present are very close in Australia; there has not been enough time and distance between colonization and more recent attempts at post-colonial reparations. As the nation struggles with coming to terms with the past, it seems history wars are being enacted once again as the landscape is re-storied with what will be written down as a new historical narrative. The nation faces new threats of colonization, and issues of the resettlement in Australia of asylum seekers are at the forefront of our national psyche. Factions of white Australians are fearing 'invasion' of the 'other', notably maligning the cultural differences of refugees, migrants and asylum seekers. Such fear of the 'other' may be associated with an anticipated loss of Australian cultural values. The Australian space in the dramatic canon has therefore become a place to adopt, refine and question traditional notions of self and nation in the larger world. Consequently, in this time of political 
unrest, economic crisis, religious extremism, terrorism and climate change, the analysis of the Australian space within the Gothic form is a provocation. Its purpose is frequently to expose conflicting and volatile contemporary issues through spatial imaginings that layer experiences of asylum, race, religion, place and space through cultural discourses. Consequently, I am proposing through this dramatic investigation of Australia as a Gothic space that as a nation we continue to struggle to define a national identity in what is a rapidly politicized multicultural and multi-racial society.

\section{AUSTRALIA AS A POLITICIZED GOTHIC NATION}

It is relevant to note that in Australia we are caught between two opposing political dynamics. On the one hand, there are those who choose to repress the collective guilt associated with our past settler and colonizing behaviours and prefer the popular mythology of our 'heroic' past. On the other hand, there are those who grew up with the 'history wars', and who may feel that this territory has been hashed over all too frequently (Maddison 2011: 68). This duality of experience is ongoing and is exacerbated by the nation experiencing new moments of social, cultural and national crisis. Discussions of identity, nation and nationhood in present-day Australia are volatile. Speaking broadly, it is no secret that in appropriating the land, white Australians have vehemently defended the right to hold sovereignty over it since colonization. However, in contemporary society both our cultural identity and the way we represent ourselves as Australians are changing. The traditional and popular mythologies we have continued to present to the world are now being critiqued. The national climate has seen Australian behaviour scrutinized on the world stage and our historical foundations of fraternity and identity being vigorously challenged. Racial and religious tensions are now encapsulated in our national discourse and are further politicized through cultural investigations in drama and theatre. This Territory, a disturbing work by playwright Noelle Janeszewska (2007), scrutinizes the violent incidents surrounding the Cronulla riots on Australia Day 2005. A politicized and Gothicized reading of the incident may be appropriate as the racial and religious riots played out against popular Australia Day events whereby the landing of Captain James Cook is celebrated as the birth of the nation. That day's riots were identified as 'The Day That Shocked the Nation' by national and international media organizations. Janeszewska's play explores how the violence perpetrated on Cronulla's multicultural community wove historical racial intolerance into present socio-cultural events. In the play, the racial violence is witnessed by a large group of young people. They all disagree about the details pertaining to the violence that generated the riot and the significance of the various roles they played in it, as their identity and what it means to be Australian are scrutinized. The play brings to the fore themes that question what white European heritage actually means in a multicultural landscape.

Similar to Salvation, the themes explored in This Territory suggest our colonial psychology is ever present. Our collective fear of the 'other' is nowhere more evident than in our migration and refugee policies. The right-wing political stance concerning these issues is becoming popular, proclaiming national uncertainties about continued European dominance. This version of recent history boasts about how rigorous we have been in defending our white Australian shores. In the late twentieth century, media attention given to over 2000 'boat people' arriving from Asia verged on hysteria. The 'Asianization' of 
Australia was blown up with little attention to caring for displaced persons or their resettlement; rather, media-fuelled questions were raised about arrivals, provoking a backlash among Australians fearing competition for jobs and housing (McQueen 2004: 316). Initially fuelled in the 1990s by propaganda from Pauline Hanson against the 'Asianization of a Nation', the growth and popularity of Hanson's One Nation Party and its nationalist and conservative agenda suggest our white identity and our sovereignty over the land are being fiercely defended. Pauline Hanson and her party members have denied claims that the party is racist, even though One Nation has called for reduced immigration, an end to benefits for Aboriginal people, an end to multiculturalism and, most recently, an end to Muslim women wearing burqas in public. Hanson is belligerent in defending her views and maintains that 'criticism is not racism'. She states that she welcomes people to Australia wherever their origin, but does not want other cultures to overly influence Australia or challenge our Australian cultural identity. In August 2018, Queensland Senator Fraser Anning called for a plebiscite as 'the final solution to the immigration problem' in the most inflammatory maiden speech to an Australian Parliament since Pauline Hanson's own address in 1996 (Koziol 2018). An advocate of the White Australia Policy, which in 1902 was legislated to limit non-British migration to Australia and allowed for the deportation of 'undesirable' people who had settled in any Australian colony prior to federation, Anning recommended radical changes to Australia's immigration program, including drastic cuts to annual migrant entry and the resumption of discrimination of immigrants based on race. Calling for Australians to 'rise up' and unleash a 'cultural counter-revolution' against the subversion of Australian society, Anning specifically targeted Muslim immigrants, asserting that they were the least able to integrate into Australian culture and society (Koziol 2018).

The politically volatile agenda endorsed by Hanson and Anning incorporates numerous anomalous national dichotomies: between white and black, citizen and migrant, place and space, refuge and refugee, reality and ideology, and inhabitant and inheritor. The endemic conflicts in these anomalies are specific to our understanding of where we are, or believe we are, positioned personally, socially and culturally in the isolating distances of our landscape (Gibson 1992). The level of attention and discourse centered on such issues suggests that white Australians are on some level afraid of our righteously defended distance being colonized by the 'other', while strict immigration, refugee and asylum-seeking policies ensure that our racial dominance remains. Those wishing to arrive and remain from distant shores are the target of our fears and the subject of white Australian conservative backlash.

Seeking out who we actually are and how we actually belong to the Australian space in a landscape that conflicts with dominant perceptions of identity and belonging is part of the post-colonial discourse explored in Australian Gothic drama. Ashcroft (2000: 20) suggests that the most fascinating feature of post-colonial societies such as Australia is a resistance that takes an array of influences exerted by the dominating power, and alters them into tools for expressing a deeply held sense of identity and cultural being that on some level resists difference. Present-day Australia is made up of many ethnically distinct immigrant and refugee community groups that are linguistically diverse and our conflicting responses to these groups may be, as Blackledge (2005) and Hatoss (2012: 48) suggest, closely linked with ideological power discourses and complex attachment or resistance to ethnicity, race, colour, culture, language and country of origin. Such discourses pose complicated 
yet interrelated questions about how the revised Australian cultural landscape and perception of Australian distance are viewed by the 'other'; these questions are consequently explored in our artistic and scholarly works.

\section{TYRANNICAL DISTANCE}

Distance can be measured as a neutral space on which cultural difference, historical memory and social organization are inscribed. As Gupta and Ferguson (1992: 7) suggest, this complex experience results in significant problems for those identified as 'other' by white Australians - those who may find themselves on the receiving end of vitriolic prejudice, and social and cultural exclusion. In the future, if current political conflict concerning refugee and immigration policy remains, these 'history wars' will be waged on a different cultural and spiritual plane. The following excerpt from Salvation examines the fears concerning invasion of the 'other' and subsequent disappearance of 'white' racial and cultural dominance:

Future: Now it's both black and white bones that whisper the stories. Of those forgotten. As they push through the dry skin of this land. The whites and blacks whose stories are imprinted in places you pass through. Those who are still there shimmerin' in the desert heat. Ya see 'em if ya look hard enough. In the flutter of the ragged curtains of those dead towns - way out there in the distance - towns ya drive through. Their names noted in plaques, scratched into tree stumps, chiselled on the face of monuments ... waiting for someone to read them out loud. Your names there too ... The others came. It was inevitable. When the others came, the ones in your future, they re-named. History. It's all just history. Was an ordinary day ... Nuthin' much went on. Same old same old really. Happens like that. History, time moves on ... Then the unexpected. No reason. You'll say nothing different went on that day. 'Cept for the arrival ... the invasion $a^{\prime}$ course. Violence. Embedded in the history of the place. Embedded out there in all that distance that's pressing down on us.

The landscape catches on fire briefly and as the flames recede, breaking through the smoke the Southern Cross appears brightly in the sky then is covered by TALL anti-aircraft carrier SHIPS approaching.

(Hassall 2013: 19)

Australia is a landscape - a Gothic space - wherein history is continually enacted and performed as part of the national socio-cultural milieu. As Carter (2010: xiv) states:

Australia was always simply a stage where history occurred, history a theatrical performance ... History is the playwright, co-ordinating facts into a coherent sequence ... the historian ... a spectator like anybody else and whatever he may think of the performance, he does not question the stage conventions.

History - past, present and future - is being written and rewritten from dramatic perspectives that embed questions associated with cultural tolerance and social change. Our distances are part of the scenographic backdrop to what is fast becoming a volatile socio-cultural milieu. 


\section{CONCLUSION}

As a scholar and an artist, I maintain foremost in my contemporary Gothic imaginings an analysis of the Australian landscape, including its strange and evocative distances. It is represented in all my investigations as a pervasive psychological presence. Its inexplicable pull informs my creative sensibility and locates my personal place as a white woman in this country. Having grown up in a regional community, my eyes were often turned to colours thrown up by the distance - to that invisible line where the red dirt met a sky the colour of kerosene. For me, the distance becomes more than a geographic reference point, and in plays like Salvation it is a phenomenon that pertains to cultural conditioning associated with space and place in the wider world. In turn its intangible pull continues to impact on Australian identity and behaviour in the immediate culturescape. In various drama education and research environments, Gothic drama can expose and provoke questions concerning behaviours particular to the national agenda. These behaviours have direct relevance to who we are as Australians and how we are perceived by the rest of the world. Plays such as Salvation ask unavoidable questions: What rules are there to being identified as an Australian? What does it mean to be recognized as a citizen of Australia, a country that is itself isolated geographically from the rest of the contemporary world by vast and dangerous distances? What does it mean to travel these distances to escape tyranny, to seek asylum, to hope to be embraced by that distant country that offers hope for a better future? How might it feel to be distanced from our national borders and boundaries? From the social and cultural landscape? What do our strange and evocative distances actually mean to and for those identified as 'other'? How do people from other lands make sense of all the distance we are used to and our Australian relationship to it?

\section{They don't really.}

A Scottish colleague once remarked to me that the Australian idea of distance is very strange. He said he just couldn't get his head around it. It is difficult to explain to those from other lands. It is challenging to actually describe how distance is an experience for us, a state of mind that is peculiar to our perception of place and space, and that in many ways dictates who we are and how we behave. The colleague supposed that if he travelled for the same amount of time from Scotland as he'd travel here in Australia to get to, say, Tennant Creek from Brisbane via Adelaide and Alice Springs, he'd end up in Moscow. Well I don't know about that, but I do know we are used to the compelling and daunting distances of our Australian landscape - distances that overlay our tyrannical history with the tyranny of our present politicized landscape.

What has remained since white Australian history was established not that very long ago is our fascination and fear of the vast distances with which we are confronted on a daily basis. It's part of us. The out there is always right here within, but also just out of reach. It is both here and there, and as scholars, artists and educators we can only try to come to terms with all it signifies. The distant horizon holds our secrets, our collective history, our past, our guilt and shame. But it also holds the promise of who we can be as a unified nation. And that is why some of us are compelled to keep returning to those kerosene coloured skies. As a playwright, scholar and educator, I cannot provide definitive answers to the questions posed above, but I can at least use them to provoke discourse and stimulate discussion on racial, religious and cultural intolerance, and investigate our seemingly tenuous place in this ancient landscape. 
Voice: We just disappear in it. It's like we [was] never here. It's like this land don't care if we [was] here or not when she starts throwin' all that distance at ya ...

Voice: Different for them blacks. Children of the distance. Thrive on it. Us white people never took as well to it. Those that are comin' [won't] never take to it either. Because others will come. We are fools to think they won't.

(Hassall 2013: 18)

\section{REFERENCES}

Ash, K., Carleton, S., Evans, G. and Harris, A. (2004), Plays from the Edge: Two Plays from Northern Australia, Brisbane: Playlab Press.

Ashcroft, W.D. (2000), Post-colonial Transformations, London: Routledge.

Betzien, A. (2005), Children of the Black Skirt, Sydney: Currency Press.

- (2007), Hoods, Sydney: Currency Press.

_ (2011), The Dark Room, Brisbane: Playlab Press.

Biskup, P. (1973), Not Slaves, Not Citizens: The Aboriginal Problem in Western Australia, 1898-1954, Brisbane: University of Queensland Press.

Blackledge, A. (2005), Discourse and Power in a Multilingual World: Discourse Approaches to Politics, Society and Culture, Amsterdam: John Benjamins.

Carleton, S. (2006), Constance Drinkwater and the Final Days of Somerset, Brisbane: Playlab Press.

- (2012), 'Australian Gothic: Theatre and the Northern turn', Australian Literary Studies, 27:2, pp. 51-66.

Carter, P. (2010), The Road to Botany Bay: An Exploration of Landscape and History, Minneapolis, MN: University of Minnesota Press.

Gelder, K. and Weaver, R. (eds) (2007), Handbook of Australian Gothic, Melbourne: Melbourne University Press.

Gibson, R. (1992), South of the West: Postcolonialism and the Narrative Construction of Australia, Bloomington, IN: Indiana University Press.

Gupta, A. and Ferguson, J. (1992), 'Beyond "culture": Space, identity and the politics of difference', Cultural Anthropology, 7:1, pp. 6-23.

Hassall, L. (2008), Post Office Rose, in M. Dorney, L. Hassall, L. Mercer and M. Mellor, Independent Brisbane: Four Plays, Brisbane: Playlab Press.

- (2011), A Contemporary Hymn, in S. Carleton, D. Evans, L. Hassall and H. Howard, I Will Kiss You in Four Places, Brisbane: Playlab Press.

_ (2013), Salvation, TEXT, 19:1 (Special issue: Scriptwriting as Creative Writing Research), pp. 1-20.

- (2015), Dust, Brisbane: Metro Arts.

Hatoss, A. (2012), 'Where are you from? Identity construction and experiences of othering in the narratives of Sudanese refugee-background Australians', Discourse and Society, 23, pp. 47-56.

Janeszewska, N. (2007), This Territory and Songket, Sydney: Currency Press.

Koziol, M. (2018), 'Senator honours white Australia Policy in first speech and calls for "final solution on immigration"', Brisbane Times, 14 August, https://www.smh.com.au/politics/federal/senator-honours-whiteaustralia-policy-in-first-speech-and-calls-for-final-solution-onimmigration-20180814-p4zxhr.html. Accessed 3 September 2018.

Maddison, S. (2011), Beyond White Guilt: The Real Challenge for Black-White Relations in Australia, Sydney: Allen \& Unwin.

McGahan, A. and Charles, S. (2009), The White Earth, Brisbane: Playlab Press. 
McQueen, H. (2004), Social Sketches of Australia, Brisbane: University of Queensland Press.

Mellor, M. (2008), Magda's Fascination with Wax Cats, in M. Dorney, L. Hassall, M. Mellor, and L. Mercer, Independent Brisbane: Four Plays, Brisbane: Playlab Press.

Reynolds, H. (1999), Why Weren't We Told? A Personal Search for the Truth About Our History, Melbourne: Viking Press.

Turcotte, G. (1998), 'Australian Gothic', Wollongong: University of Wollongong, http://ro.uow.edu.au/cgi/viewcontent.cgi? article=1060\&context= artspapers. Accessed 3 September 2018.

Van Toorn, P. (1992), 'Indigenous discourse', in Dhuulu-Yala: To Talk Straight, Canberra: Aboriginal Studies Press.

Watts, M. (2007), Not Like Beckett, Brisbane: Playlab Press.

Whitlock, G. and Carter, D. (eds) (2001), Images of Australia: An Introductory Reader in Australian Studies, Brisbane: University of Queensland Press.

\section{SUGGESTED CITATION}

Hassall, L. (2019), 'Performance and the politics of distance: Exploring the psychology of identity and culture in politicized Australian performance landscapes', Applied Theatre Research, 7:2, pp. 185-95, doi: 10.1386/ atr_00015_1

\section{CONTRIBUTOR DETAILS}

A practice-led performance researcher, Linda Hassall's expertise is in applying eco-critical and landscape analysis to Australian Gothic drama. Linda has 30 years' industry experience as a director/playwright and dramaturge. She applies her comprehensive knowledge of theatre production to her research pursuits. Her Ph.D research play Salvation Roses was a top ten finalist in the 2012 Queensland Premier's Drama Awards and was developed into the Del'Arte Chart award-winning production Salvation Project and published as Salvation (2013). Other distinctions include Matilda Award winning play Post Office Rose (2008). Linda has a strong social justice agenda, and wrote and directed The Return (2014), the outcome of an ARC project led by Professor Michael Balfour addressing post-traumatic stress (PTSD) in returning veterans.

Contact: School of Humanities, Languages and Social Sciences, Griffith University, Nathan Qld 4111, Australia.

E-mail:1.hassall@griffith.edu.au

Linda Hassall has asserted her right under the Copyright, Designs and Patents Act, 1988, to be identified as the author of this work in the format that was submitted to Intellect Ltd. 


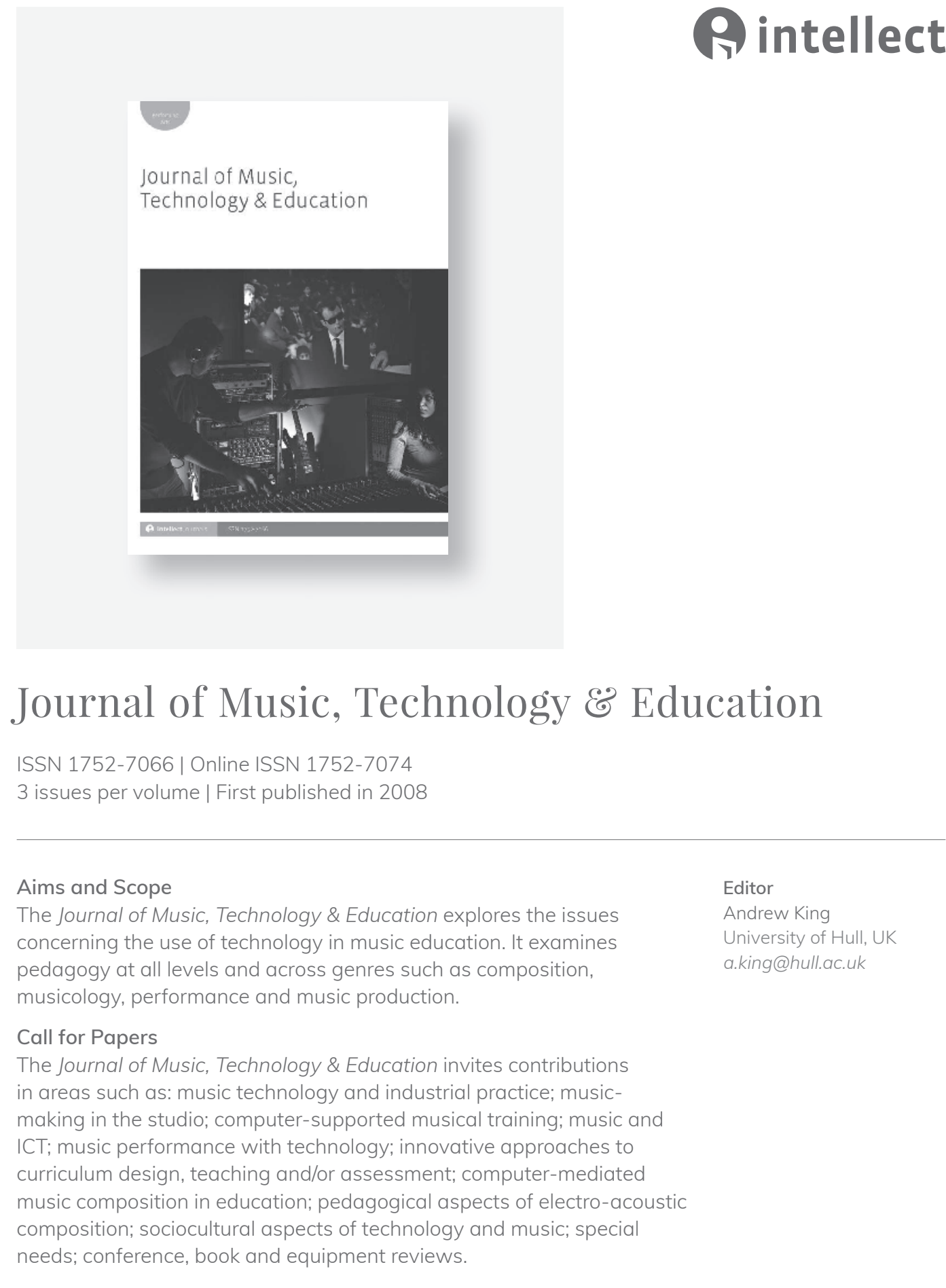

P. To order this journal online visit our website: www.intellectbooks.com
f @IntellectBooks
@IntellectBooks
의 intellectbooks
in Intellect Books 